ORIGINAL ARTICLE

\title{
Altered Ghrelin Secretion Pattern and Sense of Hunger by Providing Low and High Density Breakfast in Obese Female Adolescents
}

\author{
Ni Luh Putu Ayu Putri Sariningrat ${ }^{1 *}$, Elyana Asnar², Purwo Sri Rejeki² \\ ${ }^{1}$ Master Student of Physiology Program, Faculty of Medicine, Universitas Airlangga, Surabaya, Indonesia \\ ${ }^{2}$ Department of Physiology, Faculty of Medicine, Universitas Airlangga, Surabaya, Indonesia
}

\section{A R T I C L E I N F O}

\section{Article history:}

Received 30 April 2018

Received in revised form 17 Mei 2018

Accepted 30 Mei 2018

Available online 30 April 2018

Keywords:

Energy density

Plasma ghrelin level

Visual analog scale

Hunger.

*) Corresponding author:

putrisariputri638@gmail.com

\begin{abstract}
A B S T R A C T
Introduction: Ghrelin has been recognized to have a major influence on energy balance. Hence, the discovery of various regulatory factors that control ghrelin secretion may have major implications for the development of drugs and diet control.

Aims: This study aims to analyze differences in ghrelin secretion pattern and prevention of hunger in the provision of breakfast in low-calorie breakfast, low energy density and high energy density in obese female adolescents.

Methods: Subjects were female students aged $18-22$ years with a $B M I=25 \mathrm{~kg} / \mathrm{m}^{2}$, receiving low-calorie breakfast with low $(n=8)$ and high energy density $(n=8)$. Before the breakfast, subjects fasted for 12 hours and were subjected to plasma ghrelin level and hunger measurement using visual analog scale (VAS). Breakfast was done at 08.00, divided into three parts and each was taken for 5 minutes. Measurement of plasma ghrelin was carried out again post prandial $(P P)$ at 2 hours and 4 hours. VAS filling was done 1 hour $P P, 2$ hours $P P, 3$ hours $P P$, and 4 hours $P P$.

Results: There were differences in plasma ghrelin level, but not significant. VAS 1 analysis of hunger $(\mathrm{p}=0.040)$ at 4 hours $P P$ and VAS 3 of satiety $(\mathrm{p}=0.025)$ was significantly different at 3 hours $P P$.

Conclusion: Food density did not affect the plasma ghrelin levels. Low density foods are more effective to prevent hunger in 4 hours $P P$ and increases satiety in 3 hours $P P$.
\end{abstract}

\section{Introduction}

The prevalence of obesity in women over the age of 18 increased from $14.8 \%$ in 2007 to $32.9 \%$ in $2013{ }^{1}$. Obesity is caused by a positive energy balance ${ }^{2}$. The phenomenon of high energy density food consumption such as fast food and sugary foods has become a habit and trend for adolescents in the United States and some Asian countries including Indonesia and causing obesity 3. The large number of calories and macronutrient composition in the diet shows the effect on hunger, satiety and the desire to eat which is the mechanics of regulating hormones especially ghrelin ${ }^{4-6}$. Ghrelin has been recognized to have a major influence on energy balance ${ }^{7}$ so that the discovery of various regulatory factors that control ghrelin secretion can have major implications for drug development and diet control ${ }^{8}$

In Indonesia the diversity of traditional corn-based foods is advantageous with low energy density, rich in dietary fiber, rich in antioxidants, minerals and excellent for the prevention of degenerative diseases ${ }^{9}$. While fast food is a very popular food among teenagers in Indonesia which has high energy density because it contains a lot of fat. The results show that plasma ghrelin is influenced by food energy density. In Indonesia there are many low energy density menu. One of the issues raised in this research is Madura maize rice as low density food and fast food as high density food. How these two foods affect plasma levels of ghrelin and hunger is still not known. We suspect that low density 
foods are more effective at suppressing ghrelin plasma levels and hunger than high-density foods. The results of this study are expected to be a solution in controlling body weight through the selection of the right type of food.

\section{Methods}

This research is true experimental with time series design. Subjects were 18-22 year old female students with $\mathrm{BMI} \geq 25 \mathrm{~kg} / \mathrm{m}^{2}$, given low calorie breakfast low energy density $(n=8)$ and high density $(n=8)$. This research has been approved by the Ethics Commission of Health Research of Faculty of Public Health Airlangga University. 284-KEPK. Prior to conducting research subjects were required to fast for 12 hours. Examination of plasma ghrelin level by ELISA technique performed during fasting, 2 hours Post Prandial $(P P)$ and 4 hours $P P$. Measurement of hunger was done by filling the Visual Analogue Scale (VAS) during fasting, 1 hour $P P$, 2 hours $P P, 3$ hours $P P$ and 4 hours $P P$.

Low energy density food is a low-calorie breakfast with a density of $<1.6$ calories/gram given food in the form of Madura corn rice consisting of corn rice, pepes fish, fried fish, orem tempe, eggplant sauce, kothok salted fish, vegetable urap and water $200 \mathrm{ml}$. Madura corn rice used has a mature weight of 320 grams, with food density of $1.4 \mathrm{cal} / \mathrm{g}$, protein $22.18 \mathrm{~g}(19.47 \%)$, fat $16.42 \mathrm{~g}(32.54 \%)$, carbohydrate $56.38 \mathrm{~g}$ (49.51\%), $6.4 \mathrm{~g}$ fiber with a total energy of 455.47 cal. High energy density food is a low-calorie breakfast with a density $>2.1$ calories/gram given fast food meals consisting of fries, fried chicken with flour, tomato sauce and $200 \mathrm{ml}$ water. This food has a density of $2.2 \mathrm{cal} / \mathrm{g}$, with mature weight of $200 \mathrm{~g}$, protein $13.73 \mathrm{~g}(12.15 \%)$, fat $30.29 \mathrm{~g}(27.644 \%)$, carbohydrate $31.22 \mathrm{~g}(27.64 \%)$, fiber $1.8 \mathrm{~g}$ with total energy 451,81 cal. Before given breakfast subjects are required to fast for 12 hours and measured plasma ghrelin level with ELISA techniques and hunger with visual analog scale (VAS). Breakfast was done at 08.00 am divided into 3 parts and each eaten for 5 minutes (total 15 minutes).

Hunger is the appetite sensation assessed by the Visual Analogue Scale, which is a series of questions to assess the sensation of appetite (hunger) subjectively, consisting of $100 \mathrm{~mm}$ lines with words at each end depicting the extremes, expressing the most positive and the most negative. Subjects do not discuss or compare their rankings with each other and cannot refer to their previous rankings when marking the VAS (Flint, et al. 2000). The VAS consists of four questions about hunger, well-fed/satisfied, satiety, desire to eat. ${ }^{10}$

The data were analyzed for distribution normality with Saphiro-Wilk test, homogeneity test with lavene test and mean difference test using independent t-test for normal distribution and Mann-Whitney test for abnormal distributed. Data were analyzed using SPSS version 16. (SPSS.Inc., Chicago, IL)

\section{Results}

\section{Characteristic of Research Subject}

Subjects were 16 women with age range between 18-22 years old. Based on BMI, in groups with low energy densities $50.00 \%$ have BMI 25-29.9 whereas in high energy density group 62,5\% have BMI 30-34,9 (table 1).

\section{Level of Ghrelin Plasma}

The plasma ghrelin level is the result of blood sample measurement taken from the vein by using ELISA technique which shows plasma plasma level in $\mathrm{ng} / \mathrm{ml}$.

The mean of all plasme ghrelin on all subjects consisted of plasma ghrelin level on fasting low density group $(7.09 \pm 0.85 \mathrm{ng} / \mathrm{ml}), 2$ hours $P P(6.99 \pm 0.19$ $\mathrm{ng} / \mathrm{ml}), 4$ hours $P P$ in low density group $(7.01 \pm 0.25$ $\mathrm{ng} / \mathrm{ml})$ while the high density group $(6.93 \pm 0.22 \mathrm{ng} / \mathrm{ml})$, 2 hours $P P(7.06 \pm 0.48)$ and 4 hours $P P(6.99 \pm 0,35$ $\mathrm{ng} / \mathrm{ml}$ ). (Table 1)

Table 1. Characteristics of research subjects based on BMI

\begin{tabular}{ccccccc}
\hline \multirow{2}{*}{$\begin{array}{c}\text { BMI } \\
\left(\mathrm{kg} / \mathrm{m}^{2}\right)\end{array}$} & \multicolumn{2}{c}{ Low Density } & \multicolumn{2}{c}{ High Density } & \multicolumn{2}{c}{ Total } \\
\cline { 2 - 7 }$(\mathrm{n})$ & $\%$ & $(\mathrm{n})$ & $\%$ & $\mathrm{n}$ & $\%$ \\
\hline $25-29,9$ & 4 & 50,00 & 2 & 25,00 & 6 & 37,50 \\
\hline $30-34,9$ & 3 & 37,50 & 5 & 62,50 & 8 & 50,00 \\
\hline $35-39,9$ & 1 & 12,50 & 0 & 0 & 1 & 6,25 \\
\hline$\geq 40$ & 0 & 0 & 1 & 12,50 & 1 & 6,25 \\
\hline Total & 8 & 100 & 8 & 100 & 16 & 100 \\
\hline
\end{tabular}

The average level of plasma ghrelin showed in the low density group plasma ghrelin level after $2 \mathrm{~h} P P$ decreased rapidly and increased slowly after $4 \mathrm{hr} P P$. While in the high density group occurred otherwise after 2 hours $P P$ increased rapidly and decreased slowly after 4 hours $P P$. On the average observation of the last plasma ghrelin level of 4 hours $P P$ the low density group was $0.02 \mathrm{ng} / \mathrm{ml}$ higher than the high density group (Table 2 and Figure 1)

Table 2. Average fasting plasma ghrelin level

\begin{tabular}{ccc}
\hline $\begin{array}{c}\text { Plasma } \\
\text { Ghrelin Level }\end{array}$ & $\begin{array}{c}\text { Low Density } \\
\mathrm{X} \pm \mathrm{SD} \\
(\mathrm{ng} / \mathrm{ml})\end{array}$ & $\begin{array}{c}\text { High Density } \\
\mathrm{X} \pm \mathrm{SD} \\
(\mathrm{ng} / \mathrm{ml})\end{array}$ \\
\hline Fasting & $7,09 \pm 0,85$ & $6,93 \pm 0,22$ \\
\hline 2 Hours $P P$ & $6,99 \pm 0,19$ & $7,06 \pm 0,48$ \\
\hline 4 Hours $P P$ & $7,01 \pm 0,25$ & $6,99 \pm 0,35$ \\
\hline
\end{tabular}




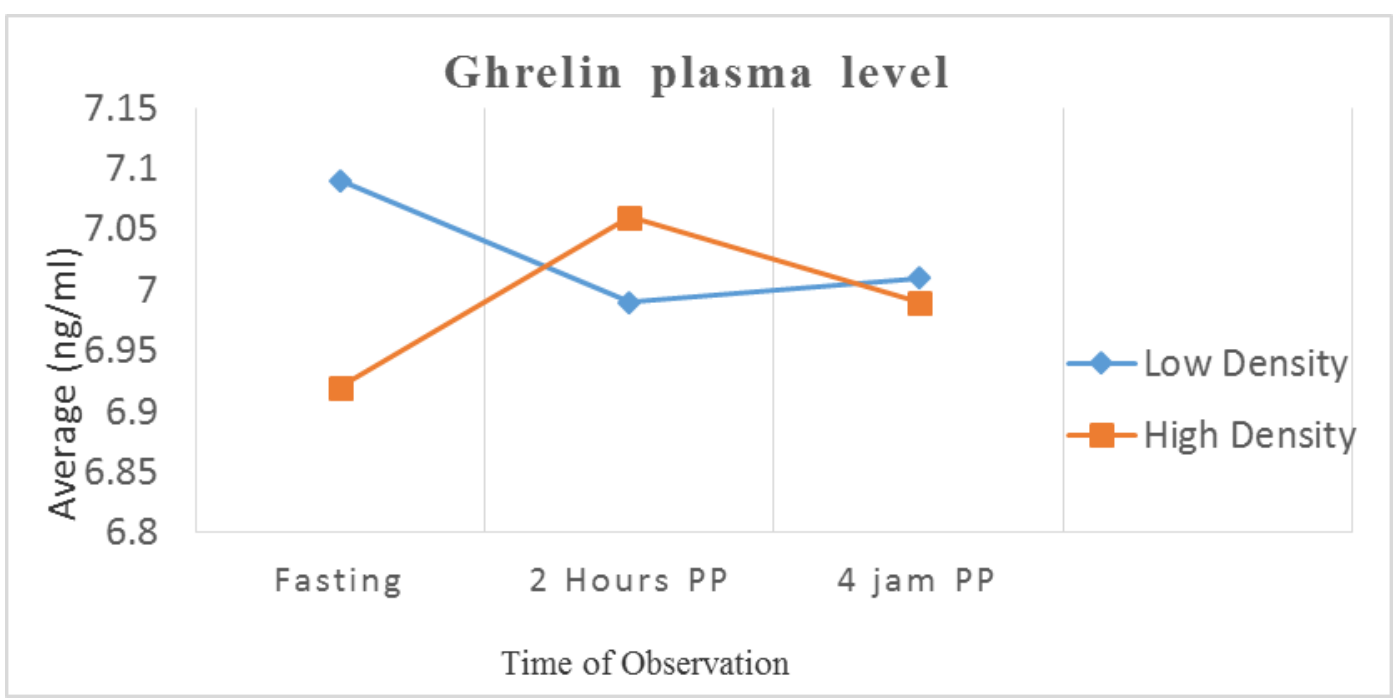

Figure 1. Average diagram of plasma ghrelin levels

Result of normality test of plasma ghrelin level during fasting, 2 hours $P P$ and 4 hours $P P$ showed p> 0,05 so it can be concluded normal distribution. Result of homogeneity test of plasma ghrelin level during fasting, 2 hour $P P$ and 4 hour $P P$ both showed fast plasma ghrelin value of significance $\mathrm{p}<0,05$ so it can be concluded not homogeneous data while plasma ghrelin 2 hours $P P$ and 4 hours $P P$ significance value $\mathrm{p}>0,05$ so it can be inferred homogeneous data. Analysis of different test of ghrelin level at fasting time, 2 hours $P P$ and 4 hours $P P$ in low density group and high density group yielded $\mathrm{p}=0,128$ (fasting), $\mathrm{p}=0,726$ (2 hours $P P$ ) and $\mathrm{p}$ $=0,904(4$ hours $P P)$. The significance value $\mathrm{p}>0,05$ then concluded there was no significant difference at fasting time, 2 hours $P P$ and 4 hours $P P$ between low density group and high group. (Table 3 )

Table 3. Different test results of fasting plasma ghrelin level, 2 hours $P P, 4$ hours $P P$ group of low density and high density group

\begin{tabular}{cccc}
\hline $\begin{array}{c}\text { Plasma } \\
\text { Ghrelin } \\
\text { Level }\end{array}$ & $\begin{array}{c}\text { Low Density } \\
\mathrm{X} \pm \mathrm{SD} \\
(\mathrm{ng} / \mathrm{ml})\end{array}$ & $\begin{array}{c}\text { High Density } \\
\mathrm{X} \pm \mathrm{SD} \\
(\mathrm{ng} / \mathrm{ml})\end{array}$ & $p$ \\
\hline Fasting & $7,09 \pm 0,85$ & $6,93 \pm 0,22$ & 0,128 \\
\hline 2 Hours $P P$ & $6,99 \pm 0,19$ & $7,06 \pm 0,48$ & 0,726 \\
\hline 4 Hours $P P$ & $7,01 \pm 0,25$ & $6,99 \pm 0,35$ & 0,904 \\
\hline
\end{tabular}

VAS was used to assess the sensitivity of appetite subjectively. It was used to assess hunger, sense of adequate eating/satisfaction, feeling of fullness and ability to eat. (Table 4) Normality test was VAS1 1 hour $P P$, VAS1 2 hours $P P$ and VAS 23 hours $P P$ p $<0.05$ (not normally distributed) either in low energy density group or high density group. Other data show $p>0.05$ (normal distribution). To observe the average difference, independent t-test was used and the result found significant difference in VAS 14 hours $P P$ with $\mathrm{p}$ value $=0,04$. A significant difference was also found in the mean VAS 33 hour $P P$ p value $=0.025$.

Table 4. Average and significance value of hunger, wellfed feeling/satisfied, satiety and ability to eat

\begin{tabular}{|c|c|c|c|}
\hline$V A S 1$ & $\begin{array}{c}\text { Low Density } \\
\mathrm{X} \pm \mathrm{SD} \\
(\mathrm{ng} / \mathrm{ml})\end{array}$ & $\begin{array}{c}\text { High Density } \\
\mathrm{X} \pm \mathrm{SD} \\
(\mathrm{ng} / \mathrm{ml})\end{array}$ & $p$ \\
\hline Fasting & $67,50 \pm 23,15$ & $65,00 \pm 25,63$ & 0,841 \\
\hline 1 hours $P P$ & $16,25 \pm 14,08$ & $25,00 \pm 20,70$ & 0,416 \\
\hline 2 hours $P P$ & $43,75 \pm 22,64$ & $45,00 \pm 16,90$ & 1.000 \\
\hline 3 hours $P P$ & $52,50 \pm 17,53$ & $55,00 \pm 22,68$ & 0,809 \\
\hline 4 hours $P P$ & $52,50 \pm 11,65$ & $70,00 \pm 18,52$ & $\begin{array}{c}0,040 \\
*\end{array}$ \\
\hline \multicolumn{4}{|l|}{ VAS 2} \\
\hline Fasting & $23,75 \pm 23,26$ & $30,00 \pm 22,04$ & 0,590 \\
\hline 1 hours $P P$ & $83,75 \pm 15,06$ & $67,50 \pm 28,66$ & 0,178 \\
\hline 2 hours $P P$ & $52,00 \pm 27,53$ & $47,50 \pm 23,15$ & 0,729 \\
\hline 3 hours $P P$ & $61,25 \pm 14,58$ & $43,75 \pm 25,04$ & 0,098 \\
\hline 4 hours $P P$ & $50,00 \pm 15,12$ & $37,50 \pm 23,15$ & 0,222 \\
\hline \multicolumn{4}{|l|}{$V A S 3$} \\
\hline Fasting & $20,00 \pm 17,73$ & $25,00 \pm 22,04$ & 0,625 \\
\hline 1 hours $P P$ & $78,75 \pm 18,85$ & $76,25 \pm 18,47$ & 0,793 \\
\hline
\end{tabular}




\section{Discussion}

Ghrelin is physiologically food initiation signal. ${ }^{4}$ In the research, the mean difference of plasma ghrelin level was not significant between low density group and high density group so it can be concluded that food density did not affect plasma ghrelin level. The results of this study are similar to other study which showed that there was no relationship between ghrelin and macronutrient intake. ${ }^{11}$ The results of Bloom et al., 2005 showed that plasma ghrelin levels after 120 minutes did not differ between low-energy food consumption, high energy foods with simple carbohydrates, high energy foods with complex carbohydrates. ${ }^{12}$ It was possible postgastric processes involve insulin secretion either directly or indirectly by stimulating incretin hormone glucagon-like peptide 1 and gastric inhibitory peptide inhibition of the stomach. Most researchers have found that insulin lowers ghrelin concentrations and depends on the presence of glucose. The mechanism of insulin has an inhibitory effect on ghrelin concentrations has not been ascertained. The effects of insulin may be mediated by direct effects on ghrelin secreting cells or by indirect effects on other humoral or central mechanisms. ${ }^{13-16}$ For further research it is advised not only to examine the ghrelin hormone but also the insulin hormone.

There was no significant difference of pattern of ghrelin secretion in fasting, 2 hours $P P$, and 4 hours $P P$. However, the value of plasma ghrelin levels at 2 hours $P P$ in low density group decreased and occurred on the contrary in high density group even increased sharply, but after 2 hours $P P$ both the ghrelin level in low density group and the high density group decreased slowly. The results were in accordance with Shiya et al., 2002 in the low-density breakfast group where plasma ghrelin circulation showed a diurnal pattern with a preprandial rise, postprandial decrease.

Plasma ghrelin levels of high density groups at 2 hours $P P$ increased probably due to the majority (75\%) including obesity second degree. According to Lucidi, 2002, the ghrelin posprandial response was dependent on insulin and may be associated with insulin resistance. ${ }^{17}$ The higher degree of obesity, the risk to experience insulin resistance is greater. The results of Daghestani's 2009 study showed that human plasma ghrelin is affected by nutritional status. ${ }^{18}$ The lack of emphasis on hunger signals on obese subjects suggests that ghrelin secretion is maximally suppressed, which may be a compensatory response to sustainable positive energy balance ${ }^{19}$. This was one of the disadvantages of this study, research subjects should have same obesity degree. Besides, the data showed not homogeneous of fasting plasma ghrelin level so it can influence food density when pressing plasma ghrelin level. In this study the menstrual factor is not controlled which according to Magdalena, 2008 the presence of estrogen receptor (ER $\alpha$ and $E R \beta)$ in pancreas $\beta$ cells will increase insulin release. While ghrelin is strongly associated with insulin. It is hoped that further research will be taken into consideration. ${ }^{20}$
Low-density breakfasts of protein and carbohydrate content are higher than high-density breakfasts. The results of Mc. Kibben (2007) research in mice showed with pure sugar and pure protein, ghrelin plasma fell rapidly by $70 \%$, while pure fat ghrelin decreased gradually to $50 \%$. This is also in line with Jacubowitzc et al. (2011), which stated that high protein and carbohydrates lead to suppression of the ghrelin hormone. High density breakfast at 1 hour $P P$ increased because of high fat content which according to Mc.Kibben (2007) fat does not maximally suppressed ghrelin only $50 \%$ so it takes time to make the ghrelin level decreased and after 2 hours of new PP decrease. Asakawa, et al., 2003 research showed that high-fat diets increased ghrelin expression in the stomach in mice, whereas Monteleone, et al. (2003) found that foods with high carbohydrates lowered ghrelin levels lower than those in high-fat foods. ${ }^{8,21,22}$

In addition, low-density breakfasts are more rich in fiber than high density groups. There is a relationship between ghrelin and intake laden wherein fiber intake significantly affects plasma ghrelin (total / acylated). Consuming fiber can also lower triglycerides and postprandial fatty acids, through decreased fat absorption. In addition, high fiber intake showed increased fat oxidation, improved fat metabolism and modulated glucose balance through delay of glucose absorption ${ }^{23}$. Several studies have shown a high intake of fiber leads to an increase in gastric transit time ${ }^{24}$. The decrease in gastric emptying causes inhibition of ghrelin secretion in the gastrointestinal tract ${ }^{25}$.

The low density breakfast also has a larger portion compared to the high density breakfast. Based on a study of Cummings et al., 2004, ghrelin pressure is more thorough in a person who eats in large portions than a person who eats in small portions. ${ }^{26}$ This is similar to the way in which calorie loads can affect appetite. So it can be described that ghrelin has an important role in food initiation.

The results of the evaluation of hunger score at 1 hour $P P, 2$ hours $P P$ and 3 hours $P P$ showed no significant difference between high density group and low density group. Only at 4 hours $P P$ was found a statistically significant difference between high density group and low density group with $\mathrm{p}=0,04$. To reinforce the results of the evaluation of hunger scores, evaluation of well-fed/satisfied, satiety and sense of desire to eat was also done. The results of the evaluation score of well-fed/satisfied at 1 hour $P P, 2$ hours $P P, 3$ hours $P P$ and 4 hours $P P$ found no significant differences between high density group and low density group

The results of the evaluation of satiety score at 1 hour $P P, 2$ hours $P P$ and 4 hours $P P$ showed no significant difference between high density group and low density group. Only at 3 hours $P P$ was found a significant difference between high density group and low density group with $\mathrm{p}=0,025$.

The results of the evaluation score of desire to eat at 1 hour $P P, 2$ hours $P P, 3$ hours $P P$ and 4 hours $P P$ 
showed no significant difference between high density group and low density group.

Foods with low energy densities can help a person lower energy intake, create a sense of satisfaction, and can control hunger. While foods with high energy densities provide tasty savory, crispy and high-fat flavors, so the consumption of foods with excessively high energy densities contributes to an increase in total energy intake that can affect weight and result in increased BMI ${ }^{27-29}$

Foods that contain lots of water and fiber have lower energy densities, while high-fat foods have higher energy density ${ }^{30}$. In this study, low-density breakfasts contained 18.6 grams of fiber, weighing 320 grams per portion to prevent hunger up to a significant 4- $P P$ observation time and significantly increase satiety at 3 hours $P P$ observation time compared to high density foods whose fiber content is only 6.8 grams, 30.29 grams with a weight of 200 grams per portion. The consumption of fiber slows the emptying of the stomach, which can cause longer satiety ${ }^{31}$. High intake of fiber improves perceptions of satiety due to increased gastric transit time ${ }^{24}$. The effect of increasing energy density on the level of gastric emptying in humans and consistently found that a high-fiber diet slowed the gastric emptying. ${ }^{32}$

\section{Conclusion}

Low-calorie breakfast low energy density is ineffective in lowering plasma levels of ghrelin compared with high energy density at 2 hours $P P$ and 4 hours $P P$ in obese female adolescents. Low-calorie breakfast low energy density is more effective at preventing hunger compared to high energy density at $4 \mathrm{~h} P P$ and suPPorted by a sense of satiety at 3 hours $P P$ on adolescent girls with obesity.

\section{Conflict of Interest}

The author stated there is no conflict of interest

\section{References}

1. Departemen KRI. Laporan Hasil Riset Kesehatan Dasar Indonesia (Riskesdas) 2013. Jakarta: Badan Litbangkes, 2013.

2. Australian Government NHaMRCDoH. Clinical Practice Guidelines for The Management of Overweight and Obesity in Adult, Adolescents and Children in Australia. Australia: Commonwealth of Australia, 2013.

3. Mudjihanto and Trintin. Kebiasaan Makan Golongan Remaja

di Enam Kota Besar di Indonesia. Penelitian Gizi dan Makanan. Bogor: Puslitbang Gizi Bogor, 1994.

4. Gavrieli A and Mantzoros CS. Novel Molecules Regulating Energy Homeostasis: Physiology and Regulation by Macronutrient Intake and Weight Loss. Endocrinology and metabolism. 2016; 31: 361-72.

5. Epstein LH, Carr KA, Lin H and Fletcher KD. Food reinforcement, energy intake, and macronutrient choice. Am J Clin Nutr. 2011; 94: 12-8.

6. Leidy HJ, Bossingham MJ, Mattes RD and Campbell WW. Increased dietary protein consumed at breakfast leads to an initial and sustained feeling of fullness during energy restriction compared to other meal times. The British journal of nutrition. 2009; 101: 798-803.

7. Klok MDS, Jakobsdottir and M.L.Drent. Role of Leptin and Ghrelin in the regulation of Food intake and Body Weight in humans: a Review. Obesity Review. 2007; 8: 21-34.

8. McKibben B. Ghrelin : The Hunger Hormone. Advanced Biochemistry. 2007.

9. Suarni. Pengembangan Pangan Tradisional Berbasis Jagung Mendukung Diversifikasi Pangan. Balai Penelitian Tanaman Serealia. 2013.

10. Muharomin IR. Peran Latihan Fisik Terhadap Nafsu makan pada Individu Overweight atau Obesitas yang Mendapatkan Konseling Gizi Tentang Low Calorie Diet. Fakultas Kedokteran. Yogyakarta: Universitas Gajah Mada, 2016.

11. Kong A, Neuhouser ML, Xiao L, Ulrich CM, McTiernan A and Foster-Schubert KE. Higher habitual intake of dietary fat and carbohydrates are associated with lower leptin and higher ghrelin concentrations in overweight and obese postmenopausal women with elevated insulin levels. Nutrition research. 2009; 29: 768-76.

12. Nuttall FQ, Almokayyad RM and Gannon MC. The ghrelin and leptin responses to short-term starvation vs a carbohydratefree diet in men with type 2 diabetes; a controlled, cross-over design study. Nutrition \& metabolism. 2016; 13: 47.

13. Parvaresh RE, Loh TP, Baig S, et al. A high carbohydrate, but not fat or protein meal attenuates postprandial ghrelin, PYY and GLP-1 responses in Chinese men. PLoS One. 2018; 13.

14. Flanagan DE, Evans ML, Monsod TP, et al. The influence of insulin on circulating ghrelin. American journal of physiology Endocrinology and metabolism. 2003; 284: E313-6. 15. Papandreou D, Karavolias C, Arvaniti F, Kafeza E and Sidawi F. Fasting Ghrelin Levels Are Decreased in Obese Subjects and Are Significantly Related With Insulin Resistance and Body Mass Index. Open access Macedonian journal of medical sciences. 2017; 5: 699-702.

16. Murdolo G, Lucidi P and Di Lerote C. Insulin is required for prandial ghrelin suppression in humans. Diabetes. 2003; 52 : 2923-7.

17. Lucidi P, Murdolo $G$ and Di Loreto C. Ghrelin is not necessary for adequate hormonal counterregulation of insulininduced hypoglycemia. Diabetes. 2002; 51: 2911- 4.

18. Dagestani MH. A Preprandial and Postprandial Plasma Levels of Ghrelin Hormone in Lean, Overweight and Obese Saudi Females. Journal of King Saud University. 2009; 21: 119-24.

19. Cummings DE and Shannon MH. Ghrelin and gastric bypass: is there a hormonal contribution to surgical weight loss? The Journal of clinical endocrinology and metabolism. 2003; 88: 2999-3002.

20. Magdalena AP, Ropero AB, Carrera MP, Colrroth CR and Baquie M-A. Pancreatic Insulin Conten Regulation by The Estrogen Reseptor ERa. PLoS ONE. 2008: 4.

21. Jakubowitcz D, Froy O, Wainstein J and Boaz M. Meal Timing and Composition Influence Ghrelin Levels, Appetite Score and Weight Loss Maintenance in Overweight and Obese Adult. Steroids. 2011; 77: 323-31.

22. Asakawa A, Inui A, Kaga T, et al. Antagonism of ghrelin receptor reduces food intake and body weight gain in mice. Gut. 2003; 52: 947-52.

23. Pierre DHS, Lhoret RR, Lavoie ME, Karrelis AD, Strycar I and Douchet E. Fiber Intake Predict Ghrelin Levels in Overweight and Obese Postmenopausal Women. European journal of endocrinology. 2009; 161: 65-72. 
24. Salas-Salvado. Effect of Two Doses of Mixture of Soluble Fibers on Body Weight and Metabolic Variabels in Overweight or Obese Patient. Brittish Journal Nutrition. 2008; 99: 1380-7.

25. Samra RA and Anderson GH. Insoluble cereal fiber reduces appetite and short-term food intake and glycemic response to food consumed 75 min later by healthy men. Am J Clin Nutr. 2007; 86: 972-9.

26. Cummings DE, Frayo RS, Marmonier C, Aubert R and Chapelot D. Plasma ghrelin levels and hunger scores in humans initiating meals voluntarily without time- and food-related cues. American journal of physiology Endocrinology and metabolism. 2004; 287: E297-304.

27. Rolls BJ, Bell EA, Cantellanos VH, Chow M, Pelkman CI and Thowart MI. Energy Density but not Fat Content of Food Afected Energy Intake in Lean and Obese Woman. Am J Clin Nutr. 1999; 69: 863-71.
28. Martin JAE, Ledikwe JH and Rolls BJ. The Influence of Food Portion Size and Energy Density on Energy Intake : Implication for Weight Maintenance. Am J Clin Nutr. 2005; 82: 2368-418.

29. Rolls BJ. The Relationship Between Dietary Energy Density and Energy Intake. Physiology \& behavior. 2009; 97: 609-15.

30. US. Departement of Health and Human Services and US Departement of Agriculture Dietary Guidelines for Americans 2005, 6th ed. Washington DC: Government Printing Office, 2005.

31. Bergmann JF, Chassany O, Pepit A, Triki R, Caulin C and Segrestaa JM. Correlation between echographic gastric emptying and appetite: influence of psyllium. Gut. 1992; 33: 1042-3.

32. Yao M and Roberts SB. Dietary energi density and weight regulation. Nutrition reviews. 2001; 59: 247-58. 